\title{
Studies on the range of tissue protein synthesis in pigs: the effect of thyroid hormones
}

\author{
BY O.SIMON, H. BERGNER AND R. MÜNCHMEYER \\ Institute of Animal Nutrition, Department of Animal Production and Veterinary Medicine, \\ Humboldt-University, Berlin, German Democratic Republic \\ AND TERESA ZEBROWSKA \\ Institute of Animal Physiology and Nutrition, Jablonna, Warsaw, Poland
}

(Received 20 March 1981-Accepted 15 June 1982)

\begin{abstract}
1. The effects of thyroid hormones on the range of tissue protein synthesis in growing pigs using the constant infusion technique with $\left[{ }^{14} \mathrm{C}\right]$ leucine and $\left[{ }^{14} \mathrm{C}\right]$ lysine were studied.

2. During a $6 \mathrm{~h}$ infusion, samples were taken from blood and, at the end of the infusion, from liver, pancreas, stomach, small and large intestines, kidney cortex, kidney medulla, muscle and skin.

3. Lower relative specific radioactivities of free leucine and lysine in several tissues were observed in the hormone-treated group than in the untreated one.

4. The range of protein synthesis rate and the daily amount of protein synthesized in tissues was higher in all tissues after application of thyroid hormones.

5. Assuming that the organs analysed represented $70 \%$ of the total trichloroacetic acid-precipitable protein of the pig, the estimated range of daily protein synthesis was $251-490$ and $312-880 \mathrm{~g}$ in untreated and hormone-treated pigs respectively.
\end{abstract}

In recent years the technique of continuous infusion of labelled amino acids has been used in experiments on the rate of tissue protein synthesis in pigs (Garlick et al. 1976; Edmunds \& Buttery, 1978; Simon, Münchmeyer et al. 1978). All the calculations of tissue protein synthesis were based on the specific radioactivity (SR) of the free and the bound amino acid in the tissue at the end of the infusion period. However, the SR of the precursor amino acids for protein synthesis lies between the SR of the free amino acids of the intracellular and the extracellular space (Airhart et al., 1974; Khairallah et al. 1977). Therefore, the rates of tissue protein synthesis estimated by the continuous infusion technique have been presented in some papers as maximum and minimum values (e.g. Garlick et al. 1973; Nicholas et al. 1977; Bohley et al. 1979; Lobley et al. 1980). For some tissues (e.g. intestine, liver) these two values differ considerably. Using a simultaneous infusion of $\left[{ }^{14} \mathrm{C}\right]$ leucine and $\left[{ }^{14} \mathrm{C}\right]$ lysine in rats it was possible to reduce the range between the maximum and minimum values (Bergner et al. 1981) compared with methods in which a single labelled amino acid was infused.

It is known that thyroxine administration increases the rate of amino acid incorporation into proteins in cell-free systems (Sokoloff et al. 1963, 1968; Brown, 1966; Carter et al. 1971; Gibson et al. 1977) and in vivo (Michels et al. 1963). Furthermore, an increased rate of tissue protein synthesis in hyperthyroid rats has been observed (Bergner et al. 1981).

The purpose of this paper is to estimate the range of the rate of tissue protein synthesis by means of simultaneous infusion of $\left[{ }^{14} \mathrm{C}\right]$ leucine and $\left[{ }^{14} \mathrm{C}\right]$ lysine in growing pigs untreated or treated with thyroid hormones. 


\section{EXPERIMENTAL}

Animals and diets

The experiment was carried out on seven castrated male pigs (Polish Landrace) of $42 \pm 2 \mathrm{~kg}$ body-weight. They were housed individually in pens except during the infusion period when they were kept in metabolism cages. Catheters were implanted into the jugular vein and into the carotid artery at least $3 \mathrm{~d}$ before the infusion. Additionally, two of the pigs (nos. 1 and 6) were fitted with duodenal re-entrant cannulas. The animals were fed twice daily with $700 \mathrm{~g}$ diet $/ \mathrm{meal}$. The diet was composed of $(\mathrm{g} / \mathrm{kg})$ : barley 700 , soya-bean oil meal 160 , starch 122, vitamin-mineral mixture (Polfamix L) 5, $\mathrm{CaCO}_{3} 10, \mathrm{NaCl} 3$.

\section{Hormonal treatment}

Four pigs were given orally $1260 \mu \mathrm{g}$ thyroxine (Hennig-Berlin $\mathrm{GmbH}$, Pharmawerke, West-Berlin) and $240 \mu \mathrm{g}$ triiodothyronine (Thyreotom, VEB Berlin Chemie, GDR) $/ \mathrm{d}$ for $9 \mathrm{~d}$ before the infusion.

\section{Isotope administration and collection of samples}

The technique was similar to that described by Simon, Münchmeyer et al. (1978). The infusion into the jugular vein started $6 \mathrm{~h}$ after a morning meal and was continued for $6 \mathrm{~h}$. During infusion the animals were not fed. The rate of infusion was $4.1 \mathrm{ml} / \mathrm{h}$ using a peristaltic pump (Technicon Instruments Co. Ltd, Basingstoke, Hants) and the infusion solution contained $(/ \mathrm{ml}): 0.9 \mathrm{mg} \mathrm{NaCl}, 0.11 \mu \mathrm{mol}$ leucine, $900 \mu \mathrm{mol}$ lysine.

The concentration of radioactivity was $8.58 \times 10^{5} \mathrm{~Bq} / \mathrm{ml}$ for $\mathrm{L}-\left[\mathrm{U}-{ }^{14} \mathrm{C}\right]$ leucine and $8.15 \times 10^{5} \mathrm{~Bq} / \mathrm{ml}$ for $\mathrm{L}-\left[\mathrm{U}-{ }^{14} \mathrm{C}\right]$ lysine (both labelled amino acids were obtained from UVVR, Prague, Czechoslovakia). The SR of the infused leucine was $7.77 \times 10^{6} \mathrm{~Bq} / \mu \mathrm{mol}$ and of the infused lysine $907 \mathrm{~Bq} / \mu \mathrm{mol}$. During the infusion period nine blood samples were taken from the carotid artery. At the end of the infusion period the animals were anaesthetized and samples from liver, pancreas, stomach, duodenum, jejunum, ileum, caecum and colon wall, kidney cortex, kidney medulla, gastrocnemius muscle, soleus muscle and skin were taken within 8-10 min.

The infusion was maintained during the sampling period. All tissues were first washed with cold saline ( $9 \mathrm{~g}$ sodium chloride/l) then placed in a plastic tube containing a known amount of cold saline and immediately frozen in a carbon dioxide-acetone bath. During the infusion of the solution containing labelled amino acids, samples of duodenal digesta from two animals were taken hourly by disconnecting the re-entrant cannula. Approximately $50 \mathrm{ml}$ digesta were collected directly into $50 \mathrm{ml}$ cold trichloroacetic acid solution (TCA; $200 \mathrm{~g} / 1)$.

\section{Preparation and analysis of samples}

The samples were prepared and analysed as described by Simon, Münchmeyer et al. (1978). Leucine and lysine were estimated in both TCA-soluble and TCA-precipitable fractions of the tissue samples and in the TCA-soluble fraction of plasma for SR.

For measurements of ${ }^{14} \mathrm{C}$ radioactivity a liquid-scintillation system (Tricarb Spectrometer 2660; Packard Instrument Co. Inc., Illinois) was used.

The concentrations of thyroxine $\left(\mathrm{T}_{4}\right)$ and triodothyronine $\left(\mathrm{T}_{3}\right)$ in blood serum were estimated in samples collected before starting the infusion. The $T_{4}$ concentration was estimated by competitive protein binding analysis (Horn, 1977) using the semi-automatic Columat-system (Sartorius-Membranfilter GmbH, Göttingen, FRG). $\mathrm{T}_{3}$ concentration was measured using a commercially available kit $\left(\mathrm{T}_{3}\right.$-RIA-kit ADW and ${ }^{125} \mathrm{~T}_{4}$ were purchased from Isocommerz GmbH, Berlin, GDR). The radioactivity of these samples was counted 
on a dual-well type detector sample changer MAG 510 (Berthold, Wildbad, FRG) in a $15-100 \mathrm{keV}$ window.

\section{Calculations}

The fractional rate of protein synthesis $\left(k_{\mathrm{s}}\right)$ was calculated using the equations derived by Garlick et al. (1973). Values of $k_{\mathrm{s}}$ were calculated using the extracellular SR (plasma) of free leucine and lysine as the precursor $S R$ as well as using intracellular SR (tissue homogenates) of free leucine and lysine as the precursor SR. For the first mode of estimation the experimentally determined rate constant $(\lambda)$ for the increase of SR of leucine and lysine and the SR of these amino acids at the end of the infusion $\left(\mathbf{S R}_{\max }\right)$ in plasma was used.

The increase of SR for leucine and lysine in plasma was described by the function

$$
\mathrm{SR}=\mathrm{SR}_{\max }\left(1-e^{-\lambda t}\right),
$$

where $\mathrm{t}$ is time. The parameters $\lambda$ and $\mathrm{SR}_{\max }$ were calculated for each animal by regression analysis using the principle of least squares. The sum of the squared deviations $Q$ was considered as a function of $\lambda$ and $\mathrm{SR}_{\max }$ :

$$
Q\left(\lambda, \mathrm{SR}_{\max }\right)=\sum_{j=1}^{n}\left(\mathrm{SR}\left(t_{j}\right)-M_{j}\right)^{2},
$$

where $M_{j}$ is a measured value at time $t_{j}$. The best estimates of $\lambda$ and $\mathrm{SR}_{\max }$ minimize $Q$ and are solutions of the equations:

$$
\begin{aligned}
\frac{\delta Q}{\delta \lambda} & =0 \\
\frac{\delta Q}{\delta \mathrm{SR}_{\max }} & =0
\end{aligned}
$$

where $\delta Q / \delta \lambda$ and $\delta Q / \delta \mathrm{SR}_{\max }$ are partial derivatives of $Q$ with respect to $\lambda$ and $\mathrm{SR}_{\max }$ respectively. Eqns (3) and (4) were solved by using the regula falsi. For these calculations a desk-top computer (Hewlett-Packard, Model 9825 A, USA) was used.

Taking the tissue SR of the free amino acids as the precursor SR for muscle and heart, the previously estimated $\lambda$ values in muscle (Simon, Münchmeyer et al. 1978) were used whereas, for other tissues, the $\lambda$ value was assumed to be the same as in plasma. The amino acid flux was calculated according to the method of Millward et al. (1975). Mean values are presented together with their standard errors. Student's $t$-test was used to test for significance of difference between sets of results.

\section{RESULTS}

Concentrations of total $T_{3}$ and total $T_{4}$ in blood serum

The concentrations of $T_{3}(\mu \mathrm{g} / \mathrm{l})$ were $0.97 \pm 0 \cdot 120$ for untreated pigs and $1 \cdot 05 \pm 0 \cdot 050$ for treated pigs (the difference was not significant). However, the $\mathrm{T}_{4}$ concentration $(\mu \mathrm{g} / \mathrm{l})$ increased significantly $(P<0 \cdot 01)$ : untreated $19 \cdot 5 \pm 1 \cdot 150$, treated $28 \cdot 0 \pm 1 \cdot 49$.

\section{$S R$ of free leucine and lysine in plasma and other tissues}

For estimation of SR of free leucine and lysine in plasma at the end of infusion a regression analysis was used. $\mathrm{SR}_{\max }$ estimated in this way (mode $\mathrm{B}$ ) was generally higher than estimates of $S_{\max }$ calculated as a mean SR during the plateau phase (mode A) (Table 1). If $\lambda$ values were low the differences between $\mathrm{SR}_{\max }$ calculated by modes $\mathrm{A}$ and $\mathrm{B}$ were considerable.

The mean $\lambda$ values calculated for free leucine and lysine in plasma were $31 \pm 4 \cdot 4 / \mathrm{d}$ and $65 \pm 12 \cdot 3 / \mathrm{d}$ respectively.

The difference between the SR of the free amino acids in several tissues and in blood 
Table 1. Comparison of the $\left[{ }^{14} \mathrm{C}\right]$ specific radioactivities of free leucine and lysine in plasma at the end of an infusion calculated as a mean value (plus standard error) from seven estimates during the plateau (mode $A$ ) and calculated by the regression analysis on the basis of nine estimates together with the rate constants $(\lambda)$ for the increase in specific radioactivities (mode B)

\begin{tabular}{|c|c|c|c|c|c|c|c|c|}
\hline \multirow{4}{*}{$\begin{array}{c}\text { Animal } \\
\text { no. }\end{array}$} & \multicolumn{6}{|c|}{ Disintegrations $/ \mathrm{min}$ per $\mu \mathrm{mol}$} & & \\
\hline & \multicolumn{4}{|c|}{ Mode A } & \multirow{2}{*}{\multicolumn{2}{|c|}{ Mode B }} & & \\
\hline & \multicolumn{2}{|c|}{ Leucine } & \multicolumn{2}{|c|}{ Lysine } & & & \multicolumn{2}{|c|}{$\lambda(/ \mathrm{d})$} \\
\hline & Mean & $\mathrm{SE}$ & Mean & SE & Leucine & Lysine & Leucine & Lysine \\
\hline 1 & 10570 & 802 & 17870 & 1372 & 12310 & 19980 & 26 & 34 \\
\hline 2 & 11560 & 865 & 20640 & 897 & 13680 & 22640 & 15 & 26 \\
\hline 3 & 13150 & 839 & 21430 & 1157 & 13830 & 21740 & 42 & 108 \\
\hline 4 & 13220 & 561 & 20590 & 1166 & 13290 & 20610 & 34 & 81 \\
\hline 5 & 14190 & 845 & 21930 & 1394 & 15980 & 22400 & 25 & 64 \\
\hline 6 & 10440 & 873 & 18440 & 713 & 10730 & 18650 & 49 & 109 \\
\hline 7 & 8980 & 683 & 15260 & 604 & 10550 & 17010 & 24 & 36 \\
\hline
\end{tabular}

Table 2. Relative specific radioactivities of free leucine and lysine in tissues of pigs after $6 \mathrm{~h}$ intravenous infusion of $L-\left[{ }^{14} \mathrm{C}\right]$ leucine and $L-\left[{ }^{14} \mathrm{C}\right]$ lysine

(Mean values with their standard errors for three untreated pigs and four hormone-treated pigs which received orally $1260 \mu \mathrm{g}$ thyroxine and $240 \mu \mathrm{g}$ triiodothyronine/d for at least $9 \mathrm{~d}$ )

\begin{tabular}{|c|c|c|c|c|c|c|c|c|}
\hline \multirow[b]{3}{*}{ Organ } & \multicolumn{4}{|c|}{ Leucine } & \multicolumn{4}{|c|}{ Lysine } \\
\hline & \multicolumn{2}{|c|}{ Untreated } & \multicolumn{2}{|c|}{$\begin{array}{l}\text { Hormone- } \\
\text { treated }\end{array}$} & \multicolumn{2}{|c|}{ Untreated } & \multicolumn{2}{|c|}{$\begin{array}{c}\text { Hormone- } \\
\text { treated }\end{array}$} \\
\hline & Mean & $\mathbf{S E}$ & Mean & SE & Mean & SE & Mean & SE \\
\hline Liver & 0.39 & 0.080 & $0 \cdot 30$ & 0.060 & 0.36 & 0.062 & $0 \cdot 24$ & 0.068 \\
\hline Pancreas & 0.39 & 0.026 & 0.30 & 0.057 & 0.52 & 0.026 & 0.44 & 0.048 \\
\hline Stomach & 0.39 & 0.042 & 0.36 & 0.093 & $0 \cdot 34$ & 0.041 & $0 \cdot 21$ & $0.015^{*}$ \\
\hline Duodenum & 0.45 & 0.020 & $0 \cdot 28$ & 0.057 & $0 \cdot 34$ & 0.012 & 0.23 & 0.056 \\
\hline Jejunum & 0.39 & 0.095 & $0 \cdot 28$ & 0.057 & 0.27 & 0.052 & $0 \cdot 17$ & 0.023 \\
\hline Ileum & $0 \cdot 37$ & $0 \cdot 103$ & 0.33 & 0.099 & $0 \cdot 24$ & 0.043 & 0.22 & $0 \cdot 048$ \\
\hline Caecum & 0.48 & 0.015 & 0.36 & 0.049 & $0 \cdot 30$ & 0.021 & $0 \cdot 18$ & $0.023^{*}$ \\
\hline Colon & 0.42 & 0.018 & 0.35 & $0 \cdot 064$ & 0.25 & 0.055 & 0.15 & 0.036 \\
\hline $\begin{array}{l}\text { Kidney } \\
\text { cortex }\end{array}$ & 0.63 & $0 \cdot 110$ & 0.51 & 0.089 & $1 \cdot 14$ & 0.042 & 0.60 & $0 \cdot 116^{* *}$ \\
\hline $\begin{array}{l}\text { Kidney } \\
\text { medulla }\end{array}$ & 0.64 & $0 \cdot 117$ & 0.45 & $0 \cdot 109$ & $1 \cdot 03$ & $0 \cdot 110$ & 0.63 & 0.173 \\
\hline $\begin{array}{l}\text { Gastrocnemius } \\
\text { muscle }\end{array}$ & 0.56 & $0 \cdot 021$ & 0.65 & $0 \cdot 108$ & 0.52 & 0.060 & 0.51 & 0.085 \\
\hline $\begin{array}{l}\text { Soleus } \\
\text { muscle }\end{array}$ & 0.54 & 0.053 & 0.66 & $0 \cdot 111$ & 0.46 & 0.003 & 0.43 & 0.054 \\
\hline Heart & 0.95 & $0 \cdot 130$ & 0.80 & 0.062 & 0.65 & $0 \cdot 100$ & 0.61 & 0.076 \\
\hline Skin & $0 \cdot 34$ & 0.046 & $0 \cdot 24$ & $0 \cdot 006$ & $0 \cdot 35$ & 0.046 & 0.30 & 0.025 \\
\hline
\end{tabular}

Differences between values for treated and untreated pigs were statistically significant: ${ }^{*} P<0 \cdot 05,{ }^{* *} P<0 \cdot 01$. 
Table 3. Example of the estimation of the range of fractional rate of protein synthesis $\left(\mathrm{k}_{\delta}\right)$ in tissues when two ${ }^{14} \mathrm{C}$-labelled amino acids were infused simultaneously into a pig

\begin{tabular}{|c|c|c|c|c|c|}
\hline \multirow[b]{3}{*}{ Organ } & \multicolumn{4}{|c|}{$k_{\mathrm{s}}(\% / \mathrm{d})$ estimated with: } & \multirow{3}{*}{$\begin{array}{c}\text { Range for } \\
k_{\mathrm{s}}(\% / \mathrm{d})\end{array}$} \\
\hline & \multicolumn{2}{|c|}{$L-\left[{ }^{14} C\right] l e u c i n e$} & \multicolumn{2}{|c|}{ L- $\left[{ }^{14} \mathrm{C}\right]$ lysine } & \\
\hline & Minimum* & Maximum* & Minimum & Maximum & \\
\hline Liver & $11 \cdot 3$ & $20 \cdot 6$ & $10 \cdot 8$ & $21 \cdot 5$ & $11 \cdot 3-20 \cdot 6$ \\
\hline Pancreas & $77 \cdot 5$ & $200 \cdot 0$ & $48 \cdot 0$ & 91.0 & $77 \cdot 5-91 \cdot 0$ \\
\hline Stomach & $16 \cdot 5$ & $37 \cdot 0$ & $11 \cdot 3$ & 35.0 & $16 \cdot 5-35 \cdot 0$ \\
\hline Duodenum & $22 \cdot 0$ & $46 \cdot 0$ & $12 \cdot 0$ & $35 \cdot 5$ & $22 \cdot 0-35 \cdot 5$ \\
\hline Jejunum & $20 \cdot 5$ & $52 \cdot 0$ & 14.5 & 55.0 & $20 \cdot 5-52 \cdot 0$ \\
\hline Ileum & $10 \cdot 0$ & $30 \cdot 0$ & 6.5 & $42 \cdot 0$ & $10 \cdot 0-30 \cdot 0$ \\
\hline Caecum & $24 \cdot 3$ & $45 \cdot 5$ & $15 \cdot 0$ & $45 \cdot 0$ & $24 \cdot 3-45 \cdot 0$ \\
\hline Colon & $13 \cdot 5$ & $30 \cdot 7$ & $8 \cdot 6$ & $28 \cdot 0$ & $13 \cdot 5-28 \cdot 0$ \\
\hline Kidney cortex & $16 \cdot 5$ & $20 \cdot 1$ & $12 \cdot 8$ & $10 \cdot 4$ & $16 \cdot 5-10 \cdot 4$ \\
\hline Kidney medulla & $17 \cdot 5$ & $29 \cdot 0$ & $14 \cdot 7$ & $15 \cdot 4$ & $17 \cdot 5-15 \cdot 4$ \\
\hline $\begin{array}{l}\text { Gastrocnemius } \\
\text { muscle }\end{array}$ & $3 \cdot 0$ & $6 \cdot 3$ & $1 \cdot 8$ & $3 \cdot 6$ & $3 \cdot 0-3 \cdot 6$ \\
\hline Soleus muscle & $2 \cdot 9$ & $6 \cdot 2$ & 1.9 & 5.0 & $2 \cdot 9-5 \cdot 0$ \\
\hline Heart & $5 \cdot 3$ & $5 \cdot 7$ & $3 \cdot 4$ & 6.0 & $5 \cdot 3-5 \cdot 7$ \\
\hline Skin & $4 \cdot 5$ & $12 \cdot 6$ & 1.9 & $7 \cdot 0$ & $4 \cdot 5-7 \cdot 0$ \\
\hline
\end{tabular}

* For details of procedures, see p. 573.

Table 4. Range of the fractional rate of tissue protein synthesis $\left(\mathbf{k}_{s}\right) \dagger$ in untreated pigs and pigs treated with thyroid hormones

(Mean values with their standard errors for the three untreated pigs and four hormone-treated pigs which received orally $1260 \mu \mathrm{g}$ thyroxine and $240 \mu \mathrm{g}$ triiodothyronine/d for at least $9 \mathrm{~d}$ )

\begin{tabular}{|c|c|c|c|c|c|c|c|c|}
\hline \multirow[b]{3}{*}{ Organ } & \multicolumn{8}{|c|}{ Range of $k_{\mathrm{s}}(\% / \mathrm{d})$} \\
\hline & \multicolumn{4}{|c|}{ Untreated } & \multicolumn{4}{|c|}{ Hormone-treated } \\
\hline & Mean & SE & Mean & SE & Mean & SE & Mean & SE \\
\hline Liver & $11 \cdot 4$ & $1 \cdot 10$ Leu $\ddagger$ & $28 \cdot 0$ & $4 \cdot 16$ Lys $\ddagger$ & $19 \cdot 0$ & $4 \cdot 20$ Leu & $80 \cdot 4$ & $30 \cdot 2$ Leu \\
\hline Pancreas & $75 \cdot 3$ & $5.73 \mathrm{Leu}$ & $88 \cdot 0$ & $7 \cdot 94 \mathrm{Lys}$ & $74 \cdot 3$ & $6.75 \mathrm{Leu}$ & $151 \cdot 0$ & 44.5 Lys \\
\hline Stomach & $13 \cdot 3$ & 4.43 Leu & $22 \cdot 9$ & $8 \cdot 87$ Lys & $15 \cdot 1$ & $1.04 \mathrm{Leu}$ & $41 \cdot 3$ & 10-4 Lys \\
\hline Duodenum & $23 \cdot 0$ & 1.83 Leu & $45 \cdot 2$ & $5 \cdot 13$ Lys & $37 \cdot 6$ & $9 \cdot 58 \mathrm{Leu}$ & $106 \cdot 0$ & $15 \cdot 1 *$ Leu \\
\hline Jejunum & $25 \cdot 0$ & 2.75 Leu & $70 \cdot 0$ & 16.0 Lys & $24 \cdot 7$ & $6 \cdot 13$ Leu & $120 \cdot 0$ & 41.9 Leu \\
\hline Ileum & $17 \cdot 7$ & 3.86 Leu & $42 \cdot 5$ & $6.61 \mathrm{Leu}$ & $23 \cdot 1$ & $7 \cdot 22$ Leu & $81 \cdot 3$ & 34.8 Lys \\
\hline Caecum & $27 \cdot 0$ & 1.65 Leu & $57 \cdot 2$ & $6.93 \mathrm{Leu}$ & $27 \cdot 6$ & $5 \cdot 39$ Leu & 88.9 & $25 \cdot 1$ Leu \\
\hline Colon & $17 \cdot 5$ & $2 \cdot 18$ Leu & $44 \cdot 0$ & $8 \cdot 33 \mathrm{Leu}$ & $28 \cdot 0$ & 6.89 Leu & $100 \cdot 0$ & 40.5 Leu \\
\hline Kidney cortex & $9 \cdot 4$ & 0.09 Lys & $15 \cdot 1$ & 1.42 Leu & $17 \cdot 2$ & $2 \cdot 26^{*}$ Leu & 37.9 & 12.6 Lys \\
\hline Kidney medulla & $11 \cdot 8$ & 1.84 Lys & $15 \cdot 7$ & $1.67 \mathrm{Leu}$ & $19 \cdot 6$ & 4.02 Leu & $34 \cdot 7$ & 14.6 Lys \\
\hline $\begin{array}{l}\text { Gastrocnemius } \\
\text { muscle }\end{array}$ & $2 \cdot 5$ & $0.26 \mathrm{Leu}$ & 3.6 & 0.23 Lys & $2 \cdot 6$ & $0.66 \mathrm{Leu}$ & $4 \cdot 8$ & $1.20 \mathrm{Leu}$ \\
\hline Soleus muscle & $2 \cdot 4$ & 0.24 Leu & $4 \cdot 7$ & 0.85 Lys & $2 \cdot 8$ & 0.71 Leu & $4 \cdot 4$ & 0.91 Leu \\
\hline Heart & $4 \cdot 6$ & 0.41 Leu & 5.9 & $0.33 \mathrm{Leu}$ & 6.0 & 0.92 Leu & $7 \cdot 5$ & 0.66 Leu \\
\hline Skin & $3 \cdot 7$ & 0.56 Leu & $8 \cdot 6$ & $3.25 \mathrm{Leu}$ & $7 \cdot 5$ & $0.73^{* *}$ Leu & $17 \cdot 1$ & 3.35 Lys \\
\hline
\end{tabular}

Differences between values for treated and untreated pigs were statistically significant: ${ }^{*} P<0 \cdot 05,{ }^{* *} P<0 \cdot 01$.

$\dagger$ For details of range-estimation of $k_{\mathrm{s}}$, see p. 576 and Table 3.

$\ddagger$ The index Leu or Lys indicates the ${ }^{14} \mathrm{C}$-amino acid by which the $k_{\mathrm{s}}$ value was estimated. 
Table 5. Amount of protein synthesized daily in selected organs of untreated pigs or pigs treated with thyroid hormones*

\begin{tabular}{|c|c|c|c|c|c|c|c|c|c|}
\hline \multirow{3}{*}{ Organ } & \multirow{3}{*}{$\begin{array}{c}\text { Relative } \\
\text { weight } \\
\text { (\% body- } \\
\text { weight) }\end{array}$} & \multicolumn{4}{|c|}{$\begin{array}{l}\text { TCA-precipitable protein } \\
\text { (mg/g tissue) }\end{array}$} & \multirow{2}{*}{\multicolumn{2}{|c|}{$\begin{array}{l}\text { Protein } \\
\text { content }(\mathrm{g})\end{array}$}} & \multirow{2}{*}{\multicolumn{2}{|c|}{$\begin{array}{l}\text { Range of protein } \\
\text { synthesis } \dagger(\mathrm{g} / \mathrm{kg} \\
\text { body-weight per d) }\end{array}$}} \\
\hline & & \multicolumn{2}{|c|}{ Untreated } & \multicolumn{2}{|c|}{$\begin{array}{l}\text { Hormone- } \\
\text { treated }\end{array}$} & & & & \\
\hline & & & & & & Untreated & $\begin{array}{l}\text { Hormone- } \\
\text { treated }\end{array}$ & Untreated & $\begin{array}{l}\text { Hormone- } \\
\text { treated }\end{array}$ \\
\hline Liver & $2 \cdot 97^{a}$ & 160 & $1 \cdot 38$ & 173 & 5.56 & 211 & 202 & $0.54-1.33$ & $0.96-4 \cdot 11$ \\
\hline Pancreas & $0 \cdot 33^{a}$ & 144 & 3.62 & 156 & $7 \cdot 1$ & 21 & 2 & $0 \cdot 36-0 \cdot 41$ & $0.38-0.76$ \\
\hline Stomach & $0 \cdot 91^{a}$ & 122 & 1.69 & 112 & $9 \cdot 25$ & 49 & 40 & $0 \cdot 16-0.25$ & $0.15-0.43$ \\
\hline Small intestine & $3 \cdot 32^{a}$ & $92 \ddagger$ & $7 \cdot 25$ & $112 \ddagger$ & 5.75 & 135 & 146 & $0 \cdot 70-1 \cdot 60$ & $0.04-3.78$ \\
\hline Caecum & $0.25^{b}$ & $76^{\circ}$ & 6.25 & $96^{\circ}$ & $5 \cdot 31$ & 8 & 9 & $0 \cdot 05-0 \cdot 11$ & $0.05-0.20$ \\
\hline Colon & $1 \cdot 62^{b}$ & 76 & 7.38 & 105 & $17 \cdot 9$ & 54 & 67 & $0 \cdot 20-0 \cdot 54$ & $0 \cdot 46-1 \cdot 70$ \\
\hline Kidney & $0.53^{a}$ & $114 \|$ & $12 \cdot 44$ & $123 \|$ & 6.94 & 27 & 26 & $0.07-0.09$ & $0.13-0.23$ \\
\hline Muscle & $45 \cdot 0^{c}$ & $142 \S$ & 11.56 & $146 \S$ & $5 \cdot 31$ & 2828 & 2581 & $1.56-2.64$ & $1.78-3.02$ \\
\hline Heart & $0.43^{a}$ & 122 & 7.88 & $133^{\circ}$ & 1.44 & 23 & 22 & $0.02-0.03$ & $0.03-0.04$ \\
\hline Skin & $7.0^{d}$ & 129 & 11.25 & 125 & 35.94 & 399 & 345 & $0.34-0.77$ & $0.66-1.50$ \\
\hline Total & & & & & & 3755 & 3458 & $4 \cdot 00-7 \cdot 77$ & $4 \cdot 64-15 \cdot 77$ \\
\hline
\end{tabular}

From ${ }^{a}$ Wiesemüller et al. (1975); ${ }^{\nu}$ own results; ${ }^{c}$ Munro (1972); ${ }^{d}$ Schmidt et al. (1933).

* For details of hormonal treatment, see Table 4.

$\dagger$ Protein synthesis was calculated using the protein content and the fractional rates of protein synthesis as shown in Table 4. The body-weight of the untreated animals was (mean \pm SE): $44 \pm 1.9 \mathrm{~kg}(n 3)$ and of the hormone-treated animals $39 \pm 3.0 \mathrm{~kg}(n 4)$.

$\ddagger$ Mean of TCA-precipitable protein content of duodenum, jejunum and ileum.

II Mean of TCA-precipitable protein content of kidney cortex and kidney medulla.

$\S$ Mean of TCA-precipitable protein content of gastrocnemius and soleus muscles.

plasma is characterized by the relative SR (Table 2), where the SR of free leucine and lysine in plasma were the reference values. A lower relative SR of both amino acids was observed in the hormone-treated group than in the untreated one; this was associated with an increase in the concentrations of free leucine and lysine in most tissues. In addition, the contents of TCA-precipitable lysine and leucine in all sections of the intestine were higher in $T_{3}$ - and $\mathrm{T}_{4}$ - treated animals than in untreated animals. With the exception of kidney the relative SR of lysine was lower than the relative SR of leucine in all organs.

\section{The range of the rate of protein synthesis}

Using the results it was possible to calculate four values for the fractional rate of protein synthesis $\left(k_{\mathrm{s}}\right)$ in each tissue. With each labelled amino acid a maximum $k_{\mathrm{s}}$ resulted from the ratio of $\mathrm{SR}$ of protein bound amino acid $\left(\mathrm{SR}_{\mathrm{b}}\right)$ : $\mathrm{SR}$ of the intracellular (homogenate) free amino acid $\left(\mathrm{SR}_{\mathrm{i}}\right)$ at the end of the infusion. A minimum $k_{\mathrm{s}}$ resulted from the ratio $\mathrm{SR}_{\mathrm{b}}: \mathrm{SR}$ of free amino acid in plasma $\left(\mathrm{SR}_{\mathrm{p}}\right)$ at the end of the infusion.

In the case of overlapping of the $k_{\mathrm{s}}$ values estimated with $\left[{ }^{14} \mathrm{C}\right]$ leucine and $\left[{ }^{14} \mathrm{C}\right] \mathrm{lysine}$, the range of the rate of tissue protein synthesis was determined by the lowest of the maximum values and the highest of the minimum values. The procedure of estimating the range of $k_{\mathrm{s}}$ is demonstrated in Table 3 using the values from one pig. With this procedure the lower and upper limits of $k_{\mathrm{s}}$ were estimated in each tissue of each animal. The results are summarized in Table 4 . The range of protein synthesis rate was generally shifted to higher values in animals treated with thyroid hormones. The most pronounced changes were observed in kidney, heart and skin but some changes in other tissues were seen (e.g. liver, duodenum, stomach). 
Table 6. Percentage contribution of tissues* to the total body protein synthesis $\dagger$ in untreated pigs or pigs treated with thyroid hormone $\ddagger$

\begin{tabular}{|c|c|c|c|c|}
\hline & \multicolumn{2}{|c|}{ Untreated } & \multicolumn{2}{|c|}{ Hormone-treated } \\
\hline & Minimum $k_{\mathrm{s}}$ & Maximum $k_{\mathrm{s}}$ & Minimum $k_{\mathrm{s}}$ & Maximum $k_{\mathrm{s}}$ \\
\hline $\begin{array}{l}\text { Gastrointestinal } \\
\text { tract } \|\end{array}$ & $19 \cdot 4$ & $22 \cdot 6$ & $21 \cdot 1$ & $27 \cdot 1$ \\
\hline $\begin{array}{l}\text { Liver + kidney+ } \\
\text { pancreas }\end{array}$ & $17 \cdot 0$ & $16 \cdot 5$ & $18 \cdot 2$ & $22 \cdot 6$ \\
\hline $\begin{array}{l}\text { Muscle + heart } \\
\text { Skin }\end{array}$ & $\begin{array}{r}27.6 \\
6.0\end{array}$ & $\begin{array}{r}24.1 \\
6.9\end{array}$ & $\begin{array}{r}22 \cdot 5 \\
8 \cdot 2\end{array}$ & $\begin{array}{r}13.6 \\
6.7\end{array}$ \\
\hline Other & 30 & 30 & 30 & 30 \\
\hline
\end{tabular}

* Calculated on the basis of tissue protein synthesis ( $\mathrm{g} / \mathrm{kg}$ body-weight per $\mathrm{d}$, see Table 5).

$\dagger$ Total body protein synthesis was calculated using the sum of protein synthesized in tissues (see Table 5) and assuming that these organs represent only $70 \%$ of total trichloroacetic acid-precipitable protein in the body.

¥ For details of hormonal treatment, see Table 4.

\| Sum of stomach, small intestine, caecum and colon (see Table 5).

Table 7. Leucine and lysine flux in three untreated pigs or four pigs treated with thyroid hormones*

\begin{tabular}{|c|c|c|c|c|c|c|c|c|c|c|c|c|c|c|}
\hline & & & \multicolumn{4}{|c|}{$\mu \mathrm{mol} / \mathrm{min}$} & \multicolumn{4}{|c|}{$\mu \mathrm{mol} / \mathrm{kg} \mathrm{W}^{0.68}$ per min } & \multicolumn{4}{|c|}{$\mathrm{g} / \mathrm{kg}$ body-weight per d } \\
\hline & \multicolumn{2}{|c|}{ Body-weight } & \multicolumn{2}{|c|}{ Leucine } & \multicolumn{2}{|c|}{ Lysine } & \multicolumn{2}{|c|}{ Leucine } & \multicolumn{2}{|c|}{ Lysine } & \multicolumn{2}{|c|}{ Leucine } & \multicolumn{2}{|c|}{ Lysine } \\
\hline & Mean & SE & Mean & SE & Mean & SE & Mean & SE & Mean & SE & Mean & SE & Mean & SE \\
\hline Untreated & $44 \cdot 3$ & 1.9 & 264 & $6 \cdot 5$ & 155 & $4 \cdot 2$ & $20 \cdot 1$ & $1 \cdot 1$ & $11 \cdot 8$ & $0 \cdot 7$ & $1 \cdot 13$ & 0.08 & 0.74 & 0.05 \\
\hline Hormone-treated & $39 \cdot 4$ & $3 \cdot 0$ & 267 & $24 \cdot 0$ & 169 & $12 \cdot 3$ & $22 \cdot 3$ & $2 \cdot 3$ & $14 \cdot 0$ & 0.9 & $1 \cdot 30$ & $0 \cdot 15$ & 0.91 & 0.06 \\
\hline
\end{tabular}

* For details of hormonal treatment, see Table 4.

The stimulating effect of the thyroid hormones on $k_{\mathrm{s}}$ in tissues was associated with a higher content of TCA-precipitable proteins in most tissues (Table 5).

Because both $k_{\mathrm{s}}$ and TCA-precipitable proteins in tissues increased under the action of thyroid hormones the daily amount of protein synthesized in tissues was higher in all tissues after application of thyroid hormones (Table 5). The contributions of individual tissues to total protein synthesis (Table 6) shows that protein synthesis in skeletal muscle and heart accounts for only $20-30 \%$ of total synthesis. A similar proportion of total protein synthesis was seen in tissues of the gastrointestinal tract or viscera.

\section{Leucine and lysine flux rates}

From the SR of free leucine and lysine in plasma at the end of the infusion period the flux rate of these amino acids was calculated (Table 7). The flux of an amino acid is the sum of its loss from blood plasma by its incorporation into protein and by its catabolism. Related to body-weight or metabolic body-weight $\left(W^{0.68}\right)$ the flux rates of leucine and lysine were increased in animals treated with thyroid hormones; however, the differences were not significant. The daily flux rates of both amino acids were 3.5 times higher than their dietary intakes. 


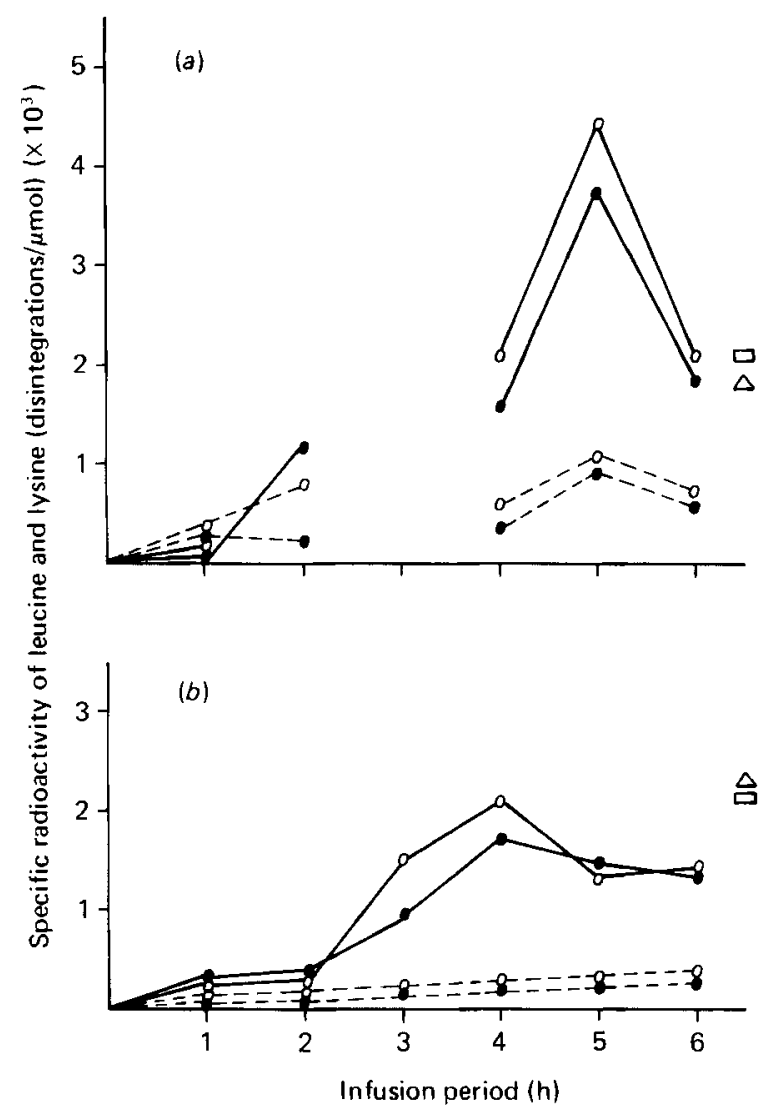

Fig. 1. Specific radioactivities (SR) of $\left[{ }^{14} \mathrm{C}\right]$ leucine $(O)$ and $\left[{ }^{14} \mathrm{C}\right]$ lysine $(\Theta)$ in the trichloroacetic acid $(200 \mathrm{~g} / \mathrm{l}$; TCA)- precipitable ( $(-)$ and TCA-soluble $(--)$ fractions of duodenal digesta of $(a)$ pig no. 1 and $(b)$ pig no. 6 during continuous infusions of $\left[{ }^{14} \mathrm{C}\right]$ leucine and $\left[{ }^{14} \mathrm{C}\right] l y s i n e$. The SR of $\left[{ }^{14} \mathrm{C}\right]$ leucine $(\triangle)$ and $\left[{ }^{14} \mathrm{C}\right]$ lysine $(\square)$ in the TCA-precipitable fraction of pancreatic tissue was estimated at $t \mathrm{l}$ : end of the infusion period.

\section{$S R$ of $\left[{ }^{14} \mathrm{C}\right]$ leucine and $\left[{ }^{14} \mathrm{C}\right]$ lysine in the duodenal digesta (Fig. I)}

The SR of both amino acids in the TCA-precipitable fraction of duodenal digesta was similar or higher during the infusion period than that in the same fraction of the pancreatic tissue at the end of the infusion. On the other hand the SR of leucine and lysine in the TCA-soluble fraction of digesta was lower than in the TCA-precipitable fraction, and lower than the TCA-precipitable fraction of pancreatic tissue after $6 \mathrm{~h}$ of infusion.

\section{DISCUSSION}

In experiments with farm animals, sampling of blood during the infusion period is possible. Because of fluctuations of the SR of free amino acids in plasma, a calculated SR for the end of infusion should be used in further estimations of the rate of protein synthesis, on the basis of the extracellular SR of the respective amino acids. As shown in Table 1, higher $\mathrm{SR}_{\max }$ result if the regression analysis was applied compared with a mean value of SR during the plateau. The plateau for SR represents only a quasi steady-state situation and is influenced by the $\lambda$ value. Therefore, the more reliable $\mathrm{SR}_{\max }$ in plasma results from the regression analysis. 
If no biopsy material is taken from tissues during infusion, the $\mathrm{SR}_{\max }$ of free amino acids in tissues can be estimated by analysis of one sample only at the end of the infusion period. Furthermore, the assumption that $\lambda$ for SR of free amino acids in intestine and liver is the same as in plasma may result in an underestimation of the maximum $k_{\mathrm{s}}$. However, taking into consideration the wide range between the minimum and maximum values of $k_{\mathrm{s}}$ (Table 4) the error introduced by this assumption is small, e.g. if in a given case a $\lambda$ value of $60 / d$ is used instead of $26 / \mathrm{d}$ the $k_{\mathrm{s}}$ would be reduced by only $7 \%$.

The problem of which precursor SR of amino acids should be used for calculations of $k_{\mathrm{s}}$ in tissues has been frequently discussed. We think that the best way to present $k_{\mathrm{s}}$ values is to calculate a maximum $k_{\mathrm{s}}$ value based on the SR of free amino acids in tissues and a minimum $k_{\mathrm{s}}$ value based on the SR of free amino acids in plasma for each tissue; this has been done by some other authors (see p. 571). However, if the relative SR of free amino acids is low, the range between the minimum and maximum $k_{\mathrm{s}}$ values estimated with one amino acid is large (Table 3 ). The use of two labelled amino acids simultaneously enables us to reduce the range of possible $k_{\mathrm{s}}$ values by limiting the range to the lowest of the two maximum values and the highest of the two minimum values for $k_{\mathrm{s}}$ (see Table 3 ).

The solution infused in the present experiment contained unlabelled lysine as well as the labelled amino acids. The amount of lysine infused during $6 \mathrm{~h}$ corresponded to $25 \%$ of the daily lysine intake of the pigs. The aim of the lysine supplementation was to reduce fluctuations of lysine concentration in plasma and to increase the relative SR of free lysine in the tissues. Compared with experiments in which infusion solutions without supplementary lysine were used (Simon, Münchmeyer et al. 1978), the relative SR increased in most tissues; however it was still smaller than the relative SR of leucine (Table 2). The exception was the relative $S R$ of $\left[{ }^{14} \mathrm{C}\right] l y s i n e$ in kidney. Values exceeding 1.0 are possible in our procedure because the maximal SR of free plasma amino acids were computer calculated on the basis of all samples collected during infusion; on the other hand, the SR of free amino acids in tissues were estimated only at the end of the infusion.

The same technique was successfully used in a similar experiment with rats (Bergner et al. 1981) in which $k_{\mathrm{s}}$ for proteins in gastrocnemius muscle were $4 \cdot 5-5 \cdot 1 \% / \mathrm{d}$ in a control group and $5 \cdot 5-6.7 \% / \mathrm{d}$ in a group treated with thyroid hormone. Although other combinations of labelled amino acids may be even more suitable than leucine and lysine, the best combination and the influence of the mode of infusion still need to be studied.

Studies of factors influencing protein synthesis should include estimates of the range of $k_{\mathrm{s}}$. In this experiment the general effect of increased thyroid hormone levels was a shift of the range of $k_{\mathrm{s}}$ toward higher values in all tissues (Table 4). Even with the values in Table 4, where the range of $k_{\mathrm{s}}$ is narrowed by the use of two amino acids, the interpretation of only the minimum or maximum $k_{\mathrm{s}}$ values would lead us to different conclusions about the magnitude of the effect of thyroid hormones on protein synthesis.

The use of only maximum $k_{\mathrm{s}}$ values would indicate for most tissues an increase of protein synthesis by $100 \%$ in hormone-treated animals while changes in minimum $k_{\mathrm{s}}$ were much lower.

It needs to be mentioned that the continuous infusion method in general probably yields low estimates of $k_{\mathrm{s}}$ in tissues with very high turnover rates, such as liver and intestine (Waterlow et al. 1978; McNurlan et al. 1979; McNurlan \& Garlick, 1980). However, for studying a large variety of tissues in farm animals this method seems to be the best one.

Other problems arise when proteins are secreted by such tissues as the pancreas and liver. According to Corring (1975) $18 \mathrm{~g}$ protein is secreted daily in pancreatic juice. As shown in Fig. 1, a larger amount of the label was found in proteins of duodenal digesta than in pancreatic tissue. The SR of leucine and lysine in the TCA-precipitable fraction of digesta reached or exceeded that of the SR of leucine and lysine in proteins of pancreatic tissue 
(while the SR in the tissue protein fraction increases continuously during the infusion period). However, the protein fraction of digesta was mixed with an unknown amount of exogenous proteins. The secretion of free $\left[{ }^{14} \mathrm{C}\right]$ leucine and $\left[{ }^{14} \mathrm{C}\right]$ lysine in pancreatic juice seems to be insignificant.

The stimulatory effect of thyroid hormones on tissue protein synthesis can be shown more clearly by the total amount of protein synthesized in tissues than by the fractional rate of protein synthesis, because of a higher content of TCA-precipitable proteins/g tissue in thyroid-hormone-treated animals (Table 5). Similar results were obtained in experiments on rats (Bergner et al. 1981).

Assuming that the organs analysed represented $70 \%$ of the total TCA-precipitable protein of the pigs, and knowing that the body-weight of the untreated pigs was $44 \pm 1.9$ and that of the treated ones $39 \pm 3 \mathrm{~kg}$, the estimated range of daily protein synthesis was $251-490$ and $312-880 \mathrm{~g}$ in untreated and hormone-treated pigs respectively. It was shown that $\mathrm{T}_{3}$ therapy in thyroidectomized rats stimulates in vivo protein synthesis in skeletal muscle (Millward et al. 1979). The daily rate of thyroxine secretion in $30-60 \mathrm{~kg}$ pigs has been estimated to be 10-12.5 $\mu \mathrm{g} / \mathrm{kg}$ body-weight (Bergner et al. 1969; Münchow \& Bergner, 1970; Münchmeyer et al. 1974).

The dose of thyroid hormones used in this experiment was approximately 3 times the normal daily secretion rate. If it is assumed that only $70 \%$ thyroid hormones were absorbed (Read et al. 1970) the actual amount entering the blood stream was only 2.5 times the normal secretion rate. Therefore, the concentrations of $T_{3}$ and $T_{4}$ were within physiological ranges. Ingram \& Evans (1980) found in 2-3 month old pigs fed with various diets that the concentrations of $T_{3}$ and $T_{4}$ in plasma ranged from 0.44 to 1.49 and from 23 to $35 \mu \mathrm{g} / 1$ respectively.

The energy cost for peptide bond synthesis has been estimated to be $3.5 \mathrm{~kJ} / \mathrm{g}$ protein (Millward et al. 1979). The energy cost of protein synthesis, however, is difficult to estimate and appears to be in the range $27-29 \mathrm{~kJ} / \mathrm{g}$ protein synthesized, including the energy content of protein (Müller \& Kirchgessner, 1979; Thorbek, 1980). When protein synthesis was regressed against heat production the slope of the line was approximately $21 \mathrm{~kJ} / \mathrm{g}$ protein synthesized (Lobley \& Reeds, 1980; Reeds et al. 1980). More exact estimates are available for the energy cost of protein deposition, which vary between 1.3 and $2.8 \mathrm{~kJ} / \mathrm{g}$ protein (Hoffmann et al. 1977; Müller \& Kirchgessner, 1979). It means that deposition of $1 \mathrm{~g}$ protein will require $31-67 \mathrm{~kJ}$. Because of the lack of accurate values for the energy cost of protein synthesis and of the relatively large range of the possible amount of synthesized protein, further calculations using values from the present experiment would not be meaningful. However, our results support the hypothesis of Sokoloff \& Kaufmann (1959) and Weiss \& Sokoloff (1963) that hypermetabolism induced by large doses of thyroxine is secondary to stimulation of protein synthesis and that even treatment with small amounts of thyroid hormones stimulates protein turnover rate and consequently increases energy expenditure. The contribution of muscle protein synthesis to total protein synthesis (Table 6) accounted for $24-28 \%$ in the control group and $14-23 \%$ in the hormone-treated group and was in the same range as in other pigs of various body-weights and in cattle (Buttery, 1980; Lobley et al. 1980). Despite the much lower total protein content of the gastrointestinal tract and viscera than in muscle, the proportions of protein synthesized by the gastrointestinal tract, viscera and muscle were similar.

The problems connected with the calculation of total protein synthesis flux rates of amino acids were recently reviewed by Reeds \& Lobley (1980). Despite the different results obtained with different labelled amino acids for interspecies comparisons, the use of $\left[{ }^{14} \mathrm{C}\right]-$ leucine was recommended. This amino acid was infused in men (Golden \& Waterlow, 1977; Garlick et al. 1980) and pigs (Reeds et al. 1980) and gave comparable results under similar 
conditions. Using U- $\left[{ }^{14} \mathrm{C}\right]$ leucine we calculated the flux rate to be $1 \cdot 13 \mathrm{~g}$ leucine $/ \mathrm{kg}$ body-weight per $\mathrm{d}$ in the untreated animals and $1.30 \mathrm{~g} / \mathrm{kg}$ body-weight per $\mathrm{d}$ in the hormone-treated animals. In our previous experiment on pigs (Simon, Bergner et al. 1978) we estimated a leucine flux of $1.21 \mathrm{~g} / \mathrm{kg}$ body-weight per $\mathrm{d}$, which supports the conclusions of Reeds \& Lobley (1980). Lysine flux is excluded from this comparison because, in contrast to other experiments, we infused unlabelled lysine and it is known that lysine oxidation is very sensitive to the dose, especially if the requirement is exceeded (Bergner \& Simon, 1976; Simon, Bergner et al. 1978). In our experiment the oxidation of leucine and lysine was not measured and therefore total body protein synthesis was not calculated from the flux rates. However, the hormonal treatment induced and increased the flux rates of leucine and lysine by 15 and $23 \%$ respectively (see Table 7 ). This stimulation is of the same order as the increase of the estimated total minimum protein synthesis (251 v. $312 \mathrm{~g} / \mathrm{d}=24 \%$ increase).

The authors are grateful to $\mathrm{Dr} \mathrm{Ch}$. Seidel for help with triidothyronine and thyroxine analysis and to Mrs I. Dressel, S. Kiewel, I. Becker and U. Kittler for skilled technical assistance.

\section{REFERENCES}

Airhart, J., Vidrich, A. \& Khairallah, E. A. (1974). Biochem. J. 140, 539.

Bergner, H., Münchow, H. \& Wirthgen, B. (1969). Arch. Tierernährung 19, 313.

Bergner, H. \& Simon, O. (1976). Arch. Tierernährung 26, 815.

Bergner, H., Simon, O., Münchmeyer, R. \& Seidel, Ch. (1981). Arch. Anim. Nutr. 31, 109.

Bohley, P., Simon, O., Bergner, H. \& Münchmeyer, R. (1979). Arch. Tierernährung 29, 607.

Brown, D. M. (1966). Endocrinology 78, 1252.

Buttery, P. J. (1980). Proc. 3rd Eur. Ass. Anim. Prod. Symp. Protein Metab. Nutr., p. 31. EAAP Publication no. 27.

Carter, W. J., Faas, F. H. \& Wynn, J. (1971). J. biol. Chem. 246, 4973.

Corring, T. (1975). Annls biol. Anim. Biochim. Biophys. 15, 115.

Edmunds, B. K. \& Buttery, P. J. (1978). Proc. Nutr. Soc. 37, 32A.

Garlick, P. J., Burk, J. L. \& Swick, R. W. (1976). Am. J. Physiol. 230, 1108

Garlick, P. J., Clugston, G. A. \& Waterlow, J. C. (1980). Am. J. Physiol. 238E 235.

Garlick, P. J., Millward, D. J. \& James, W. P. T. (1973). Biochem. J. 136, 935.

Gibson, K. D., Ben-Porath, E., Doller, H. \& Segen, N. B. J. (1977). Proc. 1lth FEBS Meeting, Abstr. B 3-4 L $1-7$.

Golden, H. N. \& Waterlow, J. C. (1977). Clin. Sci. Mol. Med. 53, 277.

Hoffmann, L., Jentsch, W., Klein, M. \& Schiemann, R. (1977). Arch. Tierernährung $27,421$.

Horn, K. (1977). Triiodothyronin-Bestimmung und pathologische Bedeutung, Berlin: Urban and Schwarzenberg. Ingram, D. L. \& Evans, S. E. (1980). Br. J. Nutr. 43, 525.

Khairallah, E. A., Airhart, J., Bruno, M. K., Puchalsky, D. \& Khairallah, L. (1977). Acta bioch. med. germ. 36, 1735.

Lobley, G. E., Milne, V., Lovie, J. M., Reeds, P. J. \& Pennie, K. (1980). Br. J. Nutr. 43, 491.

Lobley, G. E. \& Reeds, P. J. (1980). Proc. 3rd Eur. Ass. Anim. Prod. Symp. Protein Metab. Nutr., p. 80. EAAP Publication no. 27.

McNurlan, M. A. \& Garlick, P. J. (1980). Biochem. J. 186, 381.

McNurlan, M. A., Tomkins, A. M. \& Garlick, P. J. (1979). Biochem. J. 178, 373.

Michels, R., Cason, J. \& Sokoloff, L. (1963). Science 140, 1417.

Millward, D. J., Garlick, P. J., James, W. P. T., Sender, P. M. \& Waterlow, J. C. (1975). Publ. Eur. Ass. Anim. Prod., p. 49, no. 16.

Millward, D. J., Holliday, M. A., Bates, P. C., Cox, M. \& Heard, C. R. C. (1979). Proc. Nutr. Soc. 38, 33 A.

Müller, H. L. \& Kirchgessner, M. (1979). Z. Tierphysiol., Tierernährung Futtermittelkunde 42, 161.

Münchmeyer, R., Simon, O., Bergner, H., Huth, R. \& Wirthgen, B. (1974). Arch. Tierernährung $24,193$.

Münchow, H. \& Bergner, H. (1970). Arch. Tierernährung 20, 201.

Munro, H. N. (1972). In Protein and Amino Acid Functions, p. 172 [E. J. Bigwood, editor]. Oxford: Pergamon Press.

Nicholas, G. A., Lobley. G. E. \& Harris, C. I. (1977). Br. J. Nutr. 38, 1.

Read, D. G., Hays, T. \& Heshman. J. M. (1970). J. clin. Endocr. 30, 798.

Reeds, P. J., Cadenhead, A., Fuller, F., Lobley, G. E. \& McDonald, J. D. (1980). Br. J. Nutr. 43, 445.

Reeds, P. J. \& Lobley, G. E. (1980). Proc. Nutr. Soc. 39, 43. 
Schmidt, J. V., Schleinitz, M., Langenau, E. \& Zimmermann, C. (1933). Arbeiten der Deutschen Gesellschaft für Züchtungskunde. Berlin: M. and H. Scharper.

Simon, O., Bergner, H. \& Adam, K. (1978). Arch. Tierernährung 28, 609.

Simon, O., Münchmeyer, R., Bergner, H., Zebrowska, T. \& Buraczewska, L. (1978). Br. J. Nutr. $40,243$.

Sokoloff, L. \& Kaufmann, S. (1959). Science 129, 569.

Sokoloff, L., Kaufmann, S., Campbell, P. L., Francis, C. M. \& Gelboin, H. V. (1963). J. biol. Chem. $238,1432$.

Sokoloff, L., Roberts, P. A., Januska, M. M. \& Kline, J. E. (1968) Proc. natn. Acad. Sci. USA 60, 652.

Thorbek, G. (1980). Arch. Tierernährung 30, 113.

Waterlow, J. C., Garlick, P. J. \& Millward, D. J. (1978). Protein Turnover in Mammalian Tissues and in the Whole Body, pp. 366 and 469. Amsterdam: Elsevier.

Weiss, W. P. \& Sokoloff, L. (1963). Science 140, 1324.

Wiesemüller, W., Knobloch, F. \& Poppe, S. (1975). In Tierernährung und Fütterung, vol. 9, p. 139 [A. Hennig and J. Kielanowski, editors]. Berlin: VEB Deutscher Landwirtschaftverlag. 